Original Research Paper

\title{
Potential Carbon Content of Seagrass Species Diversity in Coastal Waters of Central Lombok
}

\author{
Eva Rosdiana Sari ${ }^{1 *}$, Abdul Syukur ${ }^{1}$, Moh. Liwa Ilhamdi ${ }^{1}$ \\ ${ }^{1}$ Program Studi Pendidikan Biologi, FKIP Universitas Mataram, Indonesia
}

\author{
Article History \\ Received : July $10^{\text {th }}, 2021$ \\ Revised : August $28^{\text {th }}, 2021$ \\ Accepted : September $14^{\text {th }}, 2021$ \\ Published : September $21^{\text {th }}, 2021$ \\ *Corresponding Author: \\ Eva Rosdiana Sari, \\ Program Studi Pendidikan \\ Biologi, FKIP, Universitas \\ Mataram, Indonesia \\ Email: \\ evarosdianasari98@gmail.com
}

\begin{abstract}
The marine environment has a significant role in maintaining the balance of gas exchange in the air, especially between oxygen and carbon dioxide. The potential of the marine environment for gas exchange is supported by the existence of marine ecosystems such as seagrass ecosystems. This is in accordance with the blue carbon concept which plays a role in environmental mitigation in reducing carbon through the coastal environment. Therefore, the purpose of this study was to assess the potential carbon content of the diversity of seagrass species at three locations of seagrass beds in the coastal waters of Central Lombok. The research method uses the line transect method and the ashing method. Seagrass vegetation data were analyzed using community structure analysis (diversity, uniformity and dominance). In addition, analysis of seagrass biomass and carbon content of seagrass was carried out. Furthermore, the regression analysis between seagrass density as the independent variable $(\mathrm{X})$ and the carbon content of seagrass species as the dependent variable (Y). The results of the study found 8 species of seagrass found in the waters of Central Lombok with moderate diversity ranging from 1.591.77. The value of seagrass biomass in the waters of Central Lombok is dominated by the bottom substrate with a value of $3.38 \pm 1.58$ gbk.m-2 while the upper substrate with a value of $1.69 \pm 0.98$ gbk.m-2. The carbon value of seagrass in Central Lombok waters is dominated by the bottom of the substrate with a value of $1.39 \pm 0.22$ tonC/Ha while the upper substrate is $0.72 \pm 0.13$ tonC/Ha. Meanwhile, the results of the calculation of the Pearson's correlation ( $r$ ) between the density of each type of seagrass as an independent variable $(\mathrm{X})$ and the carbon content of each type of seagrass as the dependent variable $(\mathrm{Y})$ shows the equation $\mathrm{y}=10,608 \mathrm{x}+$ 70,155 with a correlation coefficient of 0.64 which belongs to the category medium and the coefficient of determination ( $\mathrm{r} 2$ ) is 0.41 . The conclusion of this study is that there is no significant relationship between the density of each type of seagrass and the carbon of each type of seagrass as indicated by the value of Fcount (4.17) < Ftable (6.60) with a value of $=0.05$ so that $\mathrm{HO}$ is accepted and $\mathrm{Ha}$ is rejected.
\end{abstract}

Keywords: biomass, seagrass, diversity

\section{Pendahuluan}

Revolusi industri pada abad ke-18 telah menyebabkan peningkatan suhu secara global sebesar $1,1^{\circ} \mathrm{C}$ pada tahun 2018 (Hansen et al., 2018). Peningkatan suhu global tersebut disebabkan oleh meningkatnya kadar karbon di udara dan atmosfer bumi sehingga radiasi matahari terperangkap di dalam atmosfer yang menciptakan Gas Rumah Kaca (GRK) (Hilwan, 2014). Sebesar 55\% dari kandungan Gas Rumah Kaca (GRK) adalah Karbon Dioksida $\left(\mathrm{CO}_{2}\right)$ yang berasal dari sisa pembakaran bahan bakar fosil kendaraan bermotor ataupun mesin industri (Houghton et al., 2001; Rahmawati, 2011). Sebagian besar $\mathrm{CO}_{2}$ yang terdapat di bumi tersimpan dalam lautan (Rahmawati, 2011).

Pada tahun 2009 UNEP, FAO, dan UNESCO memperkenalkan konsep blue carbon sebagai upaya mitigasi lingkungan (Laffoley \& Grimdisditch, 2009). Salah satu ekosistem yang termasuk dalam konsep tersebut adalah ekosistem padang lamun. Lamun berperan dalam penyerapan karbon selama masa proses fotosintesis yang disimpan dalam bentuk biomassa (Yuniawati, 2014). Biomassa tersebut dapat berupa biomassa 
atas substrat ataupun bawah substrat (Supriadi, 2014).

Sejumlah penelitian mengenai potensi karbon padang lamun telah dilakukan. Hasil penelitian Graha (2016) menunjukan bahwa Enhalus acoroides adalah spesies yang berperan penting dalam menyimpan karbon dan rata-rata simpanan karbon padang lamun adalah 0,21 ton/ha. Hal tersebut disebabkan biomassa dan morfologi spesies menentukan nilai stok karbon lamun sehingga spesies yang memiliki morfologi besar akan memiliki potensi karbon yang tinggi (Harimbi et al., 2019).

Pulau Lombok memiliki potensi keragaman lamun yang tergolong tinggi. Hasil penelitian Rahman (2018) menunjukan bahwa ditemukan 6 spesies lamun di Poton Bako dengan potensi karbon lamun 4.48 ton.C/ha. Selain itu, perairan Lombok Tengah memiliki keragaman spesies lamun yang tinggi, yaitu ditemukannya 7 spesies di Pantai Awang, 9 spesies di Pantai Gerupuk, dan 10 spesies di Pantai Kuta (Sari et al., 2020). Penelitian ini bertujuan untuk mengestimasi potensi penyimpanan karbon pada biomassa tiap jenis lamun di bagian atas substrat (daun) dan bagian bawah substrat (akar dan rhizoma) serta hubungannya dengan kerapatan tiap jenis lamun.

\section{Bahan dan Metode}

\section{Waktu dan Tempat}

Penelitian ini dilaksanakan di Pantai Kuta, Pantai Gerupuk, dan Pantai Awang. Stasiun penelitian berjumlah 3 stasiun sebagai perwakilan dari tiap lokasi. Waktu penelitian dilaksanakan pada bulan Maret 2021. Peta lokasi penelitian sebagai berikut:

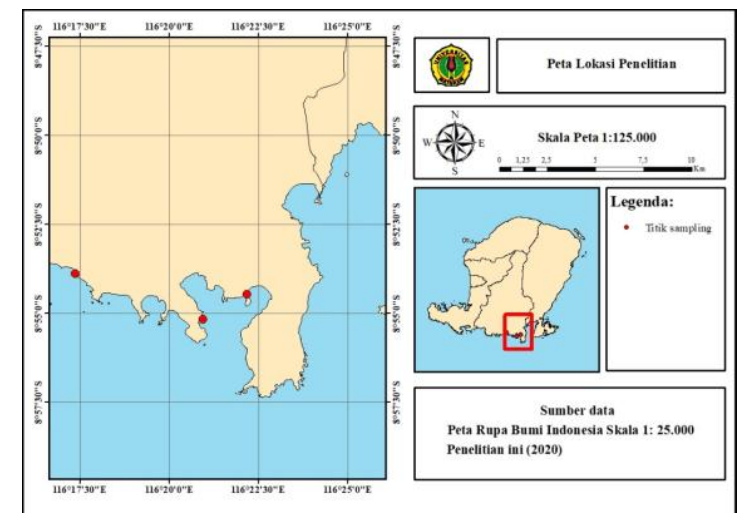

Gambar 1. Lokasi penelitian

\section{Alat dan bahan}

Alat dan bahan penelitian yang digunakan yakni GPS receiver, thermometer, refraktometer, kuadran ukuran $1 \times 1$ meter, ph meter, roll meter ukuran 100 meter, DO meter, sabit, plastic es batu, neraca analitik, oven, aluminium foil, cawan porselen, capit porselen dan tanur pengabuan (furnance).

\section{Pengambilan data}

Pengambilan data lamun menggunakan metode transek garis berpetak (Hutomo \& Nontji, 2014). Transek garis ditarik sejauh 100 meter tegak lurus garis pantai dari lamun pertama ditemukan. Kuadran diletakan pada jarak tiap 10 meter dimulai dari meter ke-0. Variabel vegetasi yang diambil adalah spesies lamun, jumlah tegakan tiap spesies, dan persen tutupan lamun. Untuk menghasilkan biomassa dari spesies lamun, data yang diambil adalah berat kering daun, rhizome, akar dan kerapatan tiap spesies. Selanjutnya untuk mendapatkan potensi kandungan karbon, data yang diambil adalah berat abu dari organ lamun (akar, rhizome, dan daun).

Pengambilan sampel lamun menggunakan metode purposive sampling dengan kriteria minimal 3 tegakan untuk lamun berukuran besar dan 6 tegakan untuk lamun berukuran kecil. Sampel lamun diambil dengan cara pemotongan rhizoma yang menjalar kesamping sampai kedalaman akar. Sampel lamun yang telah didapatkan kemudian dibersihkan dan dikemas menjadi herbarium basah (Azkab, 1999). Sampel lamun yang diambil dalam satu transek harus mewakili setiap spesies lamun yang terdapat dalam transek tersebut (Graha, 2015).

Sampel lamun yang berupa herbarium basah, dipisahkan menurut organnya yaitu akar, rhizoma dan daun, kemudian dipotong-potong menjadi bagian terkecil (Graha, 2015). Sampel lamun yang telah dikoleksi kemudian ditimbang untuk mengetahui berat basah dan ditimbang kembali setelah proses pengeringan. Nilai biomassa didapatkan dari berat kering dan kerapatan spesies lamun (Duarte, 1990). Nilai karbon didapatkan melalui perhitungan kadar karbon tiap sampel lamun yang telah melalui proses pengabuan. Kadar karbon tiap spesies lamun yang telah didapatkan kemudian dikonversi ke biomassa lamun yang terdapat di titik 0, 50, dan 100 untuk 
mewakili kandungan karbon dalam satu transek. Potensi karbon dalam satu lokasi didapatkan dari hasil perkalian antara rata-rata kandungan karbon seluruh stasiun dengan luasan lamun dalam satu lokasi (Howards et al., 2014).

\section{Analisis data}

\section{Indeks keanekaragaman (H')}

Indeks keanekaragaman dihitung dengan menggunakan rumus Shannon-Wiener (Fachrul, 2007):

$$
\mathrm{H}^{\prime}=-\sum_{i=1}^{s} P i \ln P i
$$

Keterangan:

$\mathrm{H}^{\prime}=$ Indeks keanekaragaman

$\mathrm{Pi}=\mathrm{ni} / \mathrm{N}$

$\mathrm{ni}=$ jumlah tegakan spesies ke-i

$\mathrm{N}=$ total jumlah tegakan

\section{Indeks keseragaman (E)}

Keseragaman merupakan komposisi tegakan tiap spesies yang terdapat dalam komunitas. Indeks keseragaman (Fachrul, 2007):

$\mathrm{E}=\frac{\mathrm{H}^{\prime}}{\ln \mathrm{S}}=\frac{\mathrm{H}^{\prime}}{\mathrm{Hmaks}}$

H'maks $=2 \ln S$

Keterangan:

$\mathrm{E}=$ Indeks keseragaman

$\mathrm{H}^{\prime}=$ Indeks keanekaragaman

$\mathrm{S}=$ Jumlah seluruh spesies

\section{Dominansi}

Indeks dominansi dihitung dengan menggunakan rumus:

$\mathrm{D}=\sum(\mathrm{ni} / \mathrm{N})^{2}$

Keterangan:

$\mathrm{D}=$ Indeks dominansi

$\mathrm{ni}=$ Jumlah tegakan spesies ke-i

$\mathrm{N}=$ Jumlah total seluruh tegakan

\section{Kerapatan}

Kerapatan lamun disetiap lokasi dihitung dengan menggunakan rumus sebagai berikut (Fachrul, 2007):

$\mathrm{Ki}=\frac{\mathrm{Ni}}{\mathrm{A}}$
Keterangan:

$\mathrm{Ki}=$ Kerapatan

$\mathrm{Ni}=$ Jumlah total tegakan spesies ke-i

$\mathrm{A}=$ Luas area sampling $\left(\mathrm{m}^{2}\right)$

\section{Biomassa lamun}

Rumus yang digunakan untuk menghitung biomassa ditunjukkan oleh persamaan menurut (Duarte, 1990):

$\mathrm{B}=\mathrm{W} \times \mathrm{D}$

Keterangan:

B = Biomassa Lamun (gram.m ${ }^{-2}$ )

$\mathrm{W}=$ Berat Kering sebuah Tunas Lamun $\left(\right.$ gram.tegakan $\left.^{-1}\right)$

$\mathrm{D}=$ Kepadatan Lamun (tegakan. $\mathrm{m}^{-2}$ )

\section{Pengukuran kadar karbon lamun}

Rumus yang digunakan untuk menghitung kandungan karbon jaringan lamun dengan metode pengabuan dapat dihitung dengan persamaan oleh (Helrich, 1990):

Kadar Abu $=\frac{\mathrm{c}-\mathrm{a}}{\mathrm{b}-\mathrm{a}} \mathrm{x} 100 \%$

Keterangan:

$\mathrm{a}=$ berat cawan

$\mathrm{b}=$ berat cawan + berat kering jaringan lamun

$\mathrm{c}=$ berat cawan + berat abu jaringan lamun

Bahan organik dihitung dengan metode pengabuan yaitu pengurangan berat saat pengabuan oleh Helrich (1990):

Kadar bahan organic $=\frac{[(b-a)-(c-a)]}{(b-a)} \times 100 \%$

Keterangan:

$\mathrm{a}=$ berat cawan

$\mathrm{b}=$ berat cawan + berat sampel

$\mathrm{c}=$ berat $(\mathrm{cawan}+\mathrm{abu})$

Nilai kandungan karbon jaringan lamun dihitung dengan persamaan (Helrich, 1990):

Kandungan karbon $=\frac{\text { Kadar bahan organik }}{1,724} \times 100 \%$

Keterangan:

1,724 = Nilai konstan

Nilai hasil kandungan karbon tersebut kemudian dirata-rata sebagai nilai kandungan karbon jaringan lamun (Graha, 2015). 


\section{Hubungan kerapatan lamun dengan karbon lamun}

Hubungan antara kerapatan lamun dengan karbon lamun dianalisis dengan analisis koefisien korelasi pearson (r) (Misbahuddin \& Hasan, 2013). Data variabel yang digunakan yaitu kerapatan lamun dan kandungan karbon. Berikut persamaan regresi linear sederhana yaitu sebagai berikut:

$\mathrm{r}=\frac{n \sum X Y-\left(\sum x\right)\left(\sum y\right)}{\sqrt{\left[n \sum x^{2}-\left(\sum x^{2}\right)\right]\left[n \sum x^{2}-\left(\sum y\right)^{2}\right]}}$

Tabel 1. Interpretasi koefisien korelasi " $\mathrm{r}$ " Pearson Product Moment

\begin{tabular}{ll}
\hline Interval koefisien & Tingkat hubungan \\
\hline $0,80-1,00$ & Sangat kuat \\
$0,60-0,799$ & Kuat \\
$0,40-0,599$ & Sedang \\
$0,20-0,399$ & Lemah \\
$0,00-0,199$ & Sangat lemah \\
\hline
\end{tabular}

(Sugiyono, 2018)

\section{Hasil dan Pembahasan}

\section{Kerapatan dan persen tutupan lamun}

Lamun yang ditemukan di Perairan Lombok Tengah terdiri dari 8 spesies dengan kerapatan yang berbeda-beda (Tabel 2).

Tabel 2. Kepadatan lamun (tegakan $/ \mathrm{m}^{2}$ )

\begin{tabular}{|c|c|c|c|c|c|}
\hline \multirow{2}{*}{ Jenis } & \multicolumn{3}{|c|}{ Lokasi } & \multirow{2}{*}{$\overline{\mathrm{X}}$} & \multirow{2}{*}{ SD } \\
\hline & Kuta & Gerupuk & Awang & & \\
\hline $\mathrm{Hp}$ & 14,34 & 13,73 & 25,09 & 17,72 & 6,39 \\
\hline $\mathrm{Cs}$ & 15,31 & 10,60 & 6,36 & 10,76 & 4,48 \\
\hline $\mathrm{Si}$ & 18,48 & 15,51 & 8,91 & 14,30 & 4,90 \\
\hline $\mathrm{Hu}$ & 11,02 & 10,04 & 9,26 & 10,11 & 0,88 \\
\hline $\mathrm{Cr}$ & 18,24 & 23,16 & 24,22 & 21,87 & 3,19 \\
\hline $\mathrm{Ea}$ & 14,09 & 14,94 & 6,03 & 11,69 & 4,92 \\
\hline $\mathrm{Th}$ & 14,34 & 13,24 & 10,45 & 12,68 & 2,00 \\
\hline Ho & 1,87 & 8,16 & 10,01 & 6,68 & 4,26 \\
\hline$\overline{\mathrm{X}}$ & 13,46 & 13,67 & 12,54 & 13,23 & \\
\hline $\mathrm{SD}$ & 5,26 & 4,60 & 7,65 & 4,74 & \\
\hline
\end{tabular}

Keterangan: Hp (Halodule pinifolia), Cs (Cymodocea serrulata), $\mathrm{Si}$ (Syringodium isoetifolium), $\mathrm{Hu}$ (Halodule uninervis), $\mathrm{Cr}$ (Cymodocea rotundata), (Enhalus acoroides), Th (Thalassia hemprichii), Ho (Halophila ovalis)

Kepadatan lamun di perairan Lombok Tengah adalah $13,23 \pm 4,74$ tegakan $/ \mathrm{m}^{2}$ (Tabel 2). Nilai kerapatan lamun di perairan Lombok Tengah didominasi oleh Cymodocea rotundata $(\mathrm{Cr})$ dengan nilai kerapatan yang tinggi pada lokasi, yaitu $21,87 \pm 3,19$ tegakan.m ${ }^{-2}$. Tingginya kerapatan spesies ini disebabkan spesies lamun ini dapat beradaptasi terhadap berbagai macam kondisi lingkungan (Yunita et al., 2020). Menurut Riniatsih \& Endrawati (2013), spesies lamun Cymodocea rotundata memiliki tingkat kelangsungan hidup sebesar $100 \%$ setelah masa transplatasi dengan nilai pertumbuhan $2,61 \mathrm{~mm} /$ hari untuk daun muda dan $1,86 \mathrm{~mm} /$ hari untuk daun tua. Hal tersebut disebabkan lokasi penelitian memiliki kandungan bahan organik yang relative tinggi $(5,6 \%)$ dengan tipe substrat berupa pasir halus berlumpur, sehingga memudahkan akar lamun dapat melakukan fungsinya dengan baik. Pantai Gerupuk memiliki tipe substrat pasir berlumpur sehingga spesies ini juga memiliki kerapatan yang tinggi di lokasi tersebut, yaitu 23,16 tegakan $/ \mathrm{m}^{2}$. Selain itu, lamun jenis ini memiliki persebaran yang terbatas mulai dari daerah pasang surut hingga kedalaman 10-12 meter (Azkab, 2006).

Jenis lamun Syringodium isoetifolium ( $\mathrm{Si}$ ) memiliki nilai kerapatan yang tinggi di Pantai Kuta, yaitu 18,48 tegakan.m ${ }^{-2}$ (Tabel 2). Tingginya kerapatan dari Syringodium isoetifolium disebabkan morfologi dari jenis ini tergolong kecil, yaitu dengan ukuran daun mencapai $15 \mathrm{~cm}$ berdiameter $1 \mathrm{~mm}$ (Senoaji, 2009; Adli et al., 2016). Lebih lanjut lagi, Nienhuis et al (1989) menjelaskan bahwa variasi kerapatan jenis lamun pada suatu lokasi memiliki hubungan yang signifikan terhadap morfologi dari tiap jenis lamun. Selain itu, jeni lamun ini juga memiliki bentuk daun yang kurang begitu dapat beradaptasi dengan kekeringan temporer dan daerah yang terlalu dangkal (Azkab, 2006; Ekaningrum et al., 2012). Pendapat tersebut didukung oleh Kuriandewa (2009), bahwa lamun jenis Syringodium isoetifolium tidak dapat hidup pada daerah yang mengalami pemaparan sinar matahari saat surut. Lamun jenis ini tersebar di Pantai Kuta pada daerah yang terkena surut terendah namun masih tetap tergenang oleh air laut dan bersubstrat pasir berlumpur. Hal tersebut sesuai dengan pernyataan Riniatsih (2016) bahwa lamun jenis ini dapat ditemukan pada daerah yang memiliki substrat dasar pasir berlumpur yang bercampur pecahan karang atau rubble.

Nilai kerapatan jenis tertinggi di Pantai Awang adalah Halodule pinifolia yang memiliki nilai kerapatan jenis 25,09 tegakan.m ${ }^{-2}$ (Tabel 2). 
Tingginya nilai kerapatan dari Halodule pinifolia disebabkan lamun jenis ini adalah lamun pioner yang dominan pada wilayah yang mengalami gangguan atau dengan kondisi tidak mendukung (Sakey et al., 2015). Menurut Rohmimohtarto dan Juwana (1999) lamun dengan bentuk morfologi kecil seperti Syringodium isoetifolium dan Halodule pinifolia memiliki jumlah tegakan yang lebih banyak tiap $\mathrm{m}^{2}$ dibandingkan jumlah individu dari jenis lamun yang memiliki bentuk morfologi yang lebih besar seperti dari jenis Enhalus acoroides dan Cymodocea sp., dan Thalassia hemprichii. Selain itu, substrat yang terdapat di lokasi ini adalah pasir, pasir berbatu, dan pasir berlumpur yang merupakan habitat dominan dari lamun jenis ini (Riniatsih, 2007).

Penutupan lamun adalah persentase daundaun lamun menutupi dasar perairan (substrat) dalam batasan kuadrat yang telah ditentukan dengan posisi pengamat tegak lurus kuadrat (Hutomo \& Nontji, 2014). Berikut adalah data tutupan lamun di lokasi penelitian yang dapat dilihat pada Tabel 3.

Tabel 3. Tutupan lamun (\%)

\begin{tabular}{cccccc}
\hline Jenis & Kuta & Gerupuk & Awang & $\overline{\mathbf{x}}$ & $\mathrm{SD}$ \\
\hline $\mathrm{Hp}$ & 5,25 & 4,75 & 12,07 & 7,36 & 4,09 \\
$\mathrm{Cs}$ & 8,64 & 5,15 & 2,88 & 5,56 & 2,90 \\
$\mathrm{Si}$ & 9,19 & 7,27 & 3,59 & 6,68 & 2,85 \\
$\mathrm{Hu}$ & 5,30 & 3,99 & 3,69 & 4,33 & 0,86 \\
$\mathrm{Cr}$ & 8,89 & 10,81 & 13,18 & 10,96 & 2,15 \\
$\mathrm{Ea}$ & 16,41 & 15,76 & 5,15 & 12,44 & 6,32 \\
$\mathrm{Th}$ & 8,79 & 6,97 & 5,61 & 7,12 & 1,60 \\
$\mathrm{Ho}$ & 0,96 & 3,54 & 3,84 & 2,78 & 1,58 \\
\hline Jumlah & 63,43 & 58,24 & 50,01 & 57,22 & 22,35 \\
\hline
\end{tabular}

Tutupan lamun di perairan Lombok Tengah berkisar 57,22 $\pm 22,35$ (Tabel 3) yang termasuk kedalam kategori padat (Hutomo \& Nontji, 2014). Selain itu, berdasarkan KepMenLH Nomor 200 tahun 2004 tentang Kriteria Baku Kerusakan dan Pedoman Penentuan Status Padang Lamun, status padang lamun di perairan Lombok Tengah berdasarkan nilai tutupan termasuk kondisi rusak (kurang sehat).

Tinggi rendahnya tutupan lamun berhubungan dengan ukuran daun dari jenis lamun penyusun. Jenis lamun yang memiliki ukuran morfometrik tinggi cenderung memiliki nilai tutupan yang tinggi (Hasanuddin, 2013). Spesies yang memiliki peran penting terhadap nilai tutupan lamun di perairan Lombok Tengah adalah Enhalus acoroides. Spesies ini memiliki nilai tutupan yang tinggi di Pantai Kuta dan Pantai Gerupuk, yaitu 16,41\% dab 15,76\% sedangkan di Pantai Awang hanya sebesar 5,15\% (Tabel 3). Spesies ini memiliki ukuran daun yang lebih tebal, lebar dan panjang, sehingga memungkinkan spesies ini untuk menutupi ruang yang lebih luas dari spesies lainnya (Gosari et al., 2013; Septian et al., 2016). Kondisi substrat yang terdapat di Pantai Kuta dan Pantai Gerupuk sesuai untuk kehidupan dari spesies ini yang dominan yaitu lumpur berpasir. Pendapat tersebut didukung oleh Short dan Coles (2001), bahwa spesies ini umumnya ditemukan tumbuh pada substrat berlumpur di perairan yang keruh, dan dapat membentuk spesies tunggal bahkan mendominasi suatu komunitas padang lamun.

Namun, kondisi substrat di Pantai Awang yang didominasi oleh pasir dan pasir berbatu menyebabkan spesies ini tidak dapat tumbuh maksimal sehingga tutupan lamun tertinggi di lokasi ini adalah Cymodoceae rotundata $(13,18 \%)$. Selain itu, Halodule pinifolia di lokasi ini memiliki tutupan yang tinggi, yaitu $12,07 \%$. Hal tersebut dapat disebabkan kepadatan spesies ini yang sangat tinggi, yaitu $25,09 \%$ (Tabel 2). Selain morfologi spesies lamun, kepadatan yang tinggi juga dapat mempengaruhi nilai estimasi penutupan lamun (Septian et al., 2016). Pendapat tersebut didukung oleh Nienhuis (1989), bahwa persentase tutupan lamun dipengaruhi oleh morfologi dari jenis lamun tersebut. Halodule pinifolia memiliki morfologi daun kecil sehingga memungkinkan spesies ini untuk memiliki jumlah tunas yang lebih banyak dibandingkan spesies yang memiliki morfologi daun besar seperti Enhalus acoroides.

\section{Indeks keanekaragaman, keseragaman, dan dominansi}

Nilai keanekaragaman (H') dihitung dengan menggunakan Indeks Shannon-Weinner. Hasil analisis data menunjukan bahwa nilai keanekaragaman tertinggi terdapat di Pantai Gerupuk dan terendah di Pantai Awang. Berikut adalah nilai keanekaragaman (H'), keseragaman (C), dan dominansi (E) di lokasi penelitian yang dapat dilihat pada Tabel 4. 
Tabel 4. Nilai keanekaragaman, keseragaman, dan dominansi

\begin{tabular}{llll}
\hline \multirow{2}{*}{ Lokasi } & \multicolumn{3}{l}{ Indeks } \\
\cline { 2 - 4 } & H' & $\mathrm{D}$ & $\mathrm{E}$ \\
\hline Pantai Kuta & 1,72 & 0,83 & 0,14 \\
Pantai Gerupuk & 1,77 & 0,85 & 0,14 \\
Pantai Awang & 1,59 & 0,76 & 0,17 \\
\hline
\end{tabular}

Tingkat keanekaragaman dihitung dengan menggunakan indeks keaneakragaman (H') Shannon-Wienner. Nilai keanekaragman di Pantai Kuta, Pantai Gerupuk dan Pantai Awang berturutturut adalah 1,72, 1,77, 1,59 (Tabel 4). Nilai keanerakgaman tersebut termasuk dalam kategori sedang (Magurran, 1988). Nilai keanekaragaman dari penelitian ini lebih tinggi jika dibandingkan rata-rata nilai keanekaragaman di Perairan Gili Asahan, Kabupaten Lombok Barat, yaitu 1,27 dengan nilai dominansi 0,34 (Rahman et al., 2018). Keanekaragaman jenis suatu komunitas dapat dikatakan tinggi apabila komunitas tersebut tersusun dari banyak spesies dengan kelimpahan tiap spesies merata. Sebaliknya, keanekaragaman akan rendah apabila suatu komunitas tersusun atas sedikit spesies dan kelimpahan yang tidak merata (Handayani, 2006).

Nilai keanekaragaman dapat mempengaruhi keseragaman (E) dan dominansi (C) pada suatu komunitas. Semakin kecil nilai keanekaragaman (H') akan menyebabkan nilai keseragaman (E) akan semakin kecil. Semakin kecil nilai keseragaman mengisyaratkan bahwa adanya dominansi (C) suatu spesies didalam komunitas (Insafitri, 2010). Nilai dominansi digunakan untuk mengetahui pemusatan jumlah individu pada suatu spesies didalam komunitas tertentu sedangkan nilai keseragaman menunjukan meratanya sebaran jumlah individu tiap spesies (Khouw, 2009). Rendahnya nilai keanekaragaman di Pantai Awang $\left(H^{\prime}=1,59\right)$ disebabkan nilai dominansi di lokasi tersebut lebih tinggi dibandingkan lokasi lainnya, yaitu 0,17. Hal tersebut menunjukan adanya dominansi dari suatu spesies, yaitu Halodule pinifolia dan Cymodocea rotundata. Kedua spesies tersebut memiliki nilai kerapatan yang sangat tinggi dibandingkan spesies lainnya, yaitu 24,22 tegakan. $\mathrm{m}^{-2}$ untuk Cymodocea rotundata dan 25,09 tegakan. ${ }^{-2}$ untuk Halodule pinifolia.

\section{Biomassa lamun}

Biomassa lamun yang terdapat di lokasi penelitian menunjukan bahwa biomassa lamun didominasi oleh biomassa bawah substrat (akar dan rhizome). Berikut adalah biomassa lamun di perairan Lombok Tengah yang dapat dilihat pada Tabel 5.

Tabel 5. Nilai biomassa lamun

\begin{tabular}{cccc}
\hline \multirow{2}{*}{ Lokasi } & \multicolumn{3}{c}{ Biomassa lamun $\left(\mathrm{gbk} \cdot \mathrm{m}^{-2}\right)$} \\
\cline { 2 - 4 } & $\begin{array}{c}\text { Atas } \\
\text { substrat }\end{array}$ & $\begin{array}{c}\text { Bawah } \\
\text { substrat }\end{array}$ & Total \\
\hline P. Kuta & $1,71 \pm 0,72$ & $3,70 \pm 1,44$ & $5,4 \pm 2,2$ \\
P. Gerupuk & $2,07 \pm 1,53$ & $3,91 \pm 2,03$ & $6,0 \pm 3,6$ \\
P. Awang & $1,29 \pm 0,69$ & $2,53 \pm 1,27$ & $3,8 \pm 2,0$ \\
\hline $\bar{X}$ & 1,69 & 3,38 & 5,07 \\
\hline SD & 0,98 & 1,58 & 2,56 \\
\hline Biomassa & \multicolumn{2}{c}{ lamun } & \multicolumn{2}{c}{ menggambarkan }
\end{tabular}

keseluruhan materi dari mahkluk hidup termasuk bahan organik baik yang terdapat diatas substrat ataupun dibawah substrat (Rustam, et al., 2019). Biomassa lamun didapatkan dari perkalian antara berat kering spesies lamun dengan kepadatan spesies tersebut. Total biomassa lamun yang terdapat di perairan Lombok Tengah adalah 5,07 $\pm 2,56$ gbk. $\mathrm{m}^{-2}$ (Tabel 5). Hasil ini jauh lebih sedikit dibandingkan biomassa lamun yang terdapat di Poton Bako, yaitu $984,82 \pm 138,940$ gbk.m ${ }^{-2}$ (Rahman et al., 2018). Akan tetapi, hasil ini jauh lebih tinggi jika dibandingkan dengan penelitian Marliana et al (2021) yang mendapatkan nilai biomassa lamun di

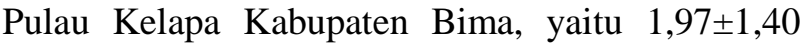
gbk.m ${ }^{-2}$.

Berdasarkan Tabel 5 dapat diketahui bahwa biomassa dibawah substrat lebih tinggi dibandingkan biomassa diatas substrat. Hal tersebut disebabkan pada bagian bawah substrat terdiri dari rhizoma dan akar lamun sedangkan bagian atas substrat hanya terdiri dari helai daun lamun (Rustam, et al., 2019). Bagian rhizome menyimpan lebih banyak biomassa dibandingkan bagian lain karena mengandung lebih banyak zat pati dan unsure hara hasil fotosintesis (Erftemeijer, 1993). Hasil penelitian Graha et al (2016) juga menyampaikan hal yang sama dimana biomassa dibawah substrat lebih besar dibandingkan diatas substrat, yaitu $60,16 \%$ berbanding $39,84 \%$. Selain itu, bagian atas substrat khususnya daun lamun rentan mengalami kerusakan fisik, akibat pemarkiran perahu nelayan yang sembarangan (Sangaji, 1994). 
Berdasarkan perhitungan biomassa lamun, nilai biomassa lamun per spesies tertinggi di Pantai Kuta, Pantai Gerupuk, dan Pantai Awang berturutturut adalah Enhalus acoroides, Cymodocea rotundata, dan Halodule pinifolia. Nilai biomassa lamun per spesies dapat dilihat pada Gambar 2.

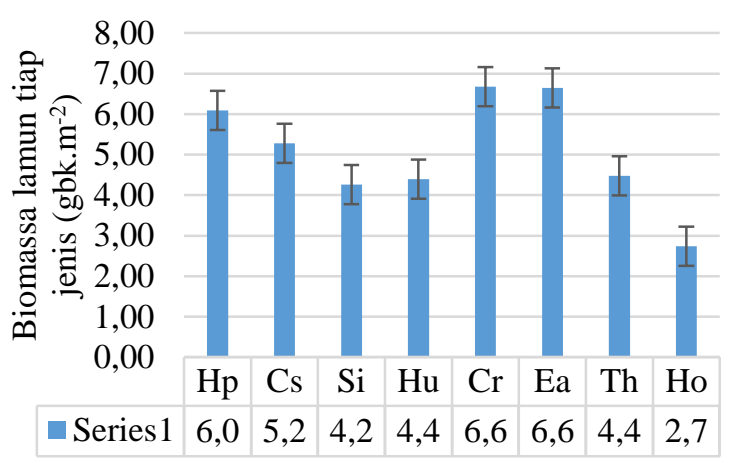

Gambar 2. Biomassa lamun per spesies lamun

Nilai biomassa lamun berkaitan dengan jenis lamun yang terdapat di ekosistem lamun. Enhalus acoroides memiliki biomassa yang tinggi dikarenakan lamun jenis ini memiliki morfologi yang paling besar diantara spesies yang ditemukan. Hal tersebut sejalan dengan pernyataan Hartati et al (2017), bahwa jenis lamun yang memiliki morfologi besar cenderung akan memberikan biomassa yang tinggi, terutama Enhalus acoroides (Laffoley \& Grimsditch, 2009). Mekipun memiliki morfologi yang kecil, Halodule pinifolia memiliki nilai biomassa yang tinggi, yaitu 6,0 gbk.m ${ }^{-2}$ (Gambar 2). Tingginya biomassa dari Halodule pinifolia dikarenakan lamun jenis ini memiliki kerapatan yang tinggi di Pantai Awang, yaitu 25,9 tegakan $/ \mathrm{m}^{2}$ (Tabel 2). Kasus yang sama juga diperlihatkan oleh tingginya nilai biomassa dari Cymodocea rotundata, yaitu 6,6 gbk. $\mathrm{m}^{-2}$. Cymodocea rotundata memiliki morfologi yang lebih kecil dibandingkan Enhalus acoroides, tetapi memiliki kepadatan yang tinggi baik di Pantai Kuta, Pantai Gerupuk, dan Pantai Awang sehingga biomassanya juga akan semakin tinggi.

Merujuk pada pernyataan Azkab (1999), bahwa nilai biomassa lamun dapat dipengaruhi oleh morfologi dan kerapatan jenis tiap spesies lamun. Pendapat yang sama disampaikan oleh Azizah et al (2017) yang menyebutkan bahwa nilai biomassa lamun dipengaruhi oleh kerapatan. Semakin tinggi kerapatan akan menyebabkan nilai biomassa akan semakin tinggi. Semakin banyak jumlah tegakan yang terdapat pada suatu eksositem, akan menyebabkan semakin banyak rimpang dan akar yang dapat menembus sedimen yang akan menyerap nutrien dari substrat (Al-Bader et al., 2014). Sejalan dengan pendapat tersebut, hasil penelitian oleh Rahman et al (2018) menunjukan bahwa biomassa lamun yang terdapat di Poton Bako berkaitan dengan nilai kerapatan lamun. Secara umum, kerapatan lamun dipengaruhi oleh faktor lingkungan, yaitu kedalaman, kecerahan, arus, dan tipe substrat (Feryatun et al., 2012). Halophila ovalis memiliki kerapatan yang rendah pada setiap lokasi penelitian sehingga nilai biomassanya juga sangat rendah, yaitu 2,7 gbk. ${ }^{-2}$. Rendahnya kerapatan dari Halophila ovalis dikarenakan spesies ini memiliki morfologi daun yang kecil dan sangat rentan terhadap arus (Setyawati et al., 2014).

\section{Karbon lamun}

Biomassa lamun yang terdapat di lokasi penelitian menunjukan bahwa kandungan karbon lamun didominasi oleh biomassa bawah substrat (akar dan rhizome). Berikut adalah kandungan karbon lamun di perairan Lombok Tengah yang dapat dilihat pada Tabel 6 .

Tabel 6. Nilai karbon lamun

\begin{tabular}{cccc}
\hline \multirow{2}{*}{ Lokasi } & \multicolumn{3}{c}{ Karbon lamun (TonC/Ha) } \\
\cline { 2 - 4 } & $\begin{array}{c}\text { Atas } \\
\text { substrat }\end{array}$ & $\begin{array}{c}\text { Bawah } \\
\text { substrat }\end{array}$ & Total \\
\hline Kuta & 0.72 & 1.50 & 2.23 \\
Gerupuk & 0.85 & 1.53 & 2.38 \\
Awang & 0.58 & 1.13 & 1.71 \\
\hline$\overline{\mathrm{x}}$ & 0.72 & 1.39 & 2.10 \\
\hline SD & 0.13 & 0.22 & 0.35 \\
\hline
\end{tabular}

Hasil analisis dengan menggunakan metode pengabuan menghasilkan kandungan karbon bagian atas substrat dan bagian bawah substrat (Gambar 3). Kandungan karbon tertinggi terdapat pada bagian bawah substrat adalah 1,39 ton $\mathrm{C} / \mathrm{Ha}$. Hasil tersebut sesuai dengan penelitian Rahadiarta et al (2018) dimana kandungan karbon bawah susbtrat lebih tinggi dibandingkan dengan atas substrat. Menurut Supriadi (2014), tingginya nilai kandungan karbon pada bagian bawah substrat dikarenakan karbon akan terakumulasi pada sedimen

Berdasarkan perhitungan karbon lamun, nilai karbon lamun per spesies tertinggi di Pantai 
Kuta dan Gerupuk adalah Enhalus acoroides sedangkan di Pantai Awang adalah Cymodocea rotundata. Nilai karbon lamun per spesies dapat dilihat pada Gambar 4.

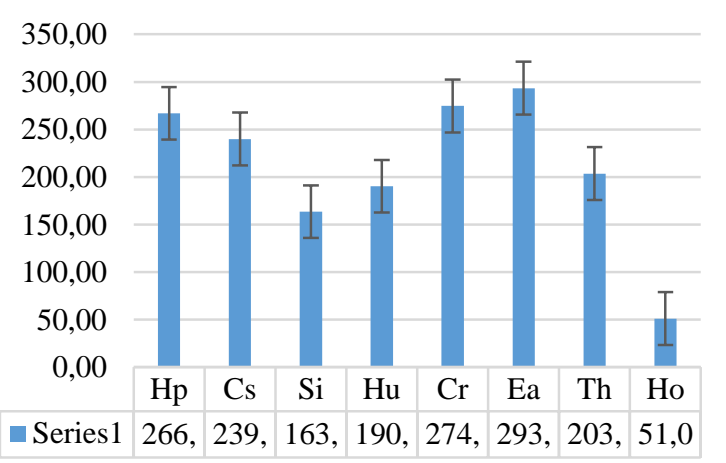

Gambar 4. Kandungan karbon lamun per spesies

Berdasarkan gambar 4 tingginya kandungan karbon didominasi oleh Halodule pinifolia, Enhalus acoroides dan Cymodocea rotundata. Tingginya kandungan karbon pada spesies Enhalus acoroides dan Cymodocea rotundata disebabkan morfologi daun kedua spesies tersebut lebih besar sehingga kemampuan fotosintesisnya lebih besar per tegakannya (Arthana, 2004). Selain itu, Cymodocea rotundata dan Halodule pinifolia memiliki kerapatan yang lebih tinggi dibandinkan spesies lainnya di setiap lokasi (Tabel 2). Tingginya kerapatan lamun spesies ini akan meningkatkan nilai biomassa sehingga kandungan karbon akan meningkat. Menurut Wardah (2009), variasi kandungan karbon akan dipengaruhi oleh biomassa lamun. Semakin tinggi biomassa lamun maka akan semakin tinggi kandungan karbonnya.

\section{Hubungan kerapatan lamun perjenis dengan kandungan karbon perjenis}

Hasil analisis korelasi pearson's (r) menunjukan bahwa terdapat hubungan yang sedang antara variable $\mathrm{x}$ (kerapatan lamun) dengan variable y (kandungan karbon lamun). Hal tersebut ditunjukan dengan nilai korelasi pearson's (r) berada pada nilai 0,64. Menurut Misbahuddin \& Hasan (2014), nilai koefisien korelasi Pearson (r) 0,40-0,70 termasuk kategori sedang/cukup. Nilai koefisien determinasi (R) sebesar 0,4106 menunjukan bahwa variasi dari variable y (karbon lamun) yang disebabkan oleh variable $\mathrm{x}$ (kerapatan lamun) hanya sebesar $41,06 \%$ dan 58,94\% sisanya adalah faktor lain (Gambar 5).

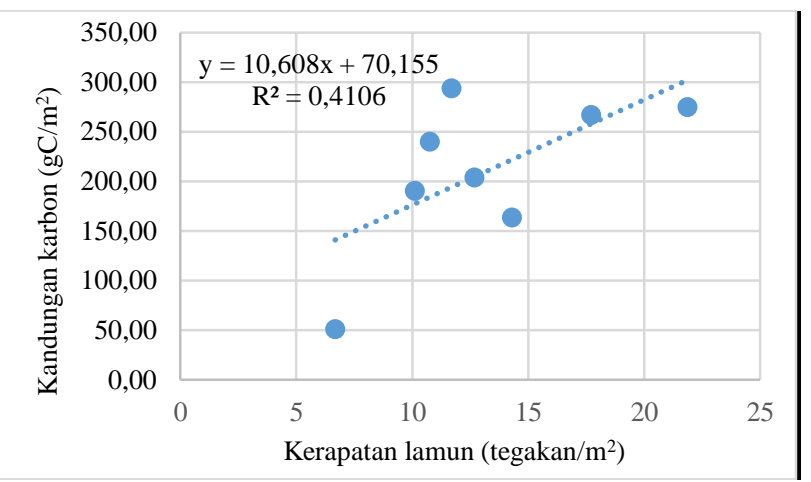

Gambar 5. Hubungan kerapatan lamun dengan karbon lamun

Hasil analisis regresi linier (Gambar 5) menunjukukan persamaan $\mathrm{y}=10,608 \mathrm{x}+70,155$ yang menjelaskan bahwa setiap kenaikan 1 variabel $\mathrm{X}$ (kerapatan lamun) akan meningkatkan nilai variable Y (karbon lamun). Hasil analisis dengan menggunakan $f$-test menunjukan bahwa tidak terdapat hubungan yang signifikan antara variable $\mathrm{x}$ (kerapatan) dengan variable y (karbon) yang dimana $\mathrm{f}_{\text {hitung }}(4,17)<\mathrm{f}_{\text {tabel }(0.05,1,5)}(6,60)$ sehingga $\mathrm{H} 0$ diterima dan Ha ditolak. Pendapat yang sama disampaikan oleh Khairunnisa et al (2018), bahwa tidak terdapat hubungan yang berbanding lurus antara kerapatan lamun terhadap kandungan karbon. Hal tersebut dikarenakan lamun yang memiliki morfologi lebih kecil cenderung memiliki kerapatan yang tinggi.

\section{Kesimpulan}

Berdasarkan penelitian yang dilakukan dapat disimpulkan nilai indeks keanekaragam lamun di Perairan Lombok Tengah berkisar 1,59 - 1,77 yang termasuk kedalam ketegori sedang. Nilai biomassa lamun di lokasi penelitian adalah 5,07 $\pm 2,56$ gbk. $\mathrm{m}^{-2}$ dengan bagian bawah substrat memiliki biomassa yang lebih tinggi dibandingkan bagian atas substrat. Nilai karbon lamun di perairan Lombok Tengah adalah 2,10 $\pm 0,35 \mathrm{TonC} / \mathrm{Ha}$ didominasi oleh bagian bawah substrat dibandingkan bagian atas substrat. Hasil analisis regresi linier menunjukan persamaan y $=10,608 x+70,155$ yang menandakan bahwa kenaikan variable $(\mathrm{X})$ akan meningkatkan nilai variable (Y). Hasil análisis menggunakan $F$-test menunjukan bahwa nilai $\mathrm{f}_{\text {hitung }}(4,17)<\mathrm{f}_{\text {tabel }(0.05,1,5)}$ $(6,60)$ yang dimana $\mathrm{H}_{0}$ diterima dan $\mathrm{H}_{\mathrm{a}}$ ditolak sehingga tidak ada hubungan signifikan antara 
kerapatan tiap jenis lamun terhadap nilai karbon tiap jenis lamun.

\section{Ucapan terima kasih}

Ucapan terima kasih kepada Tim Dosen penelitian Dasar Unggulan Pengurusan Tinggi FKIP UNRAM tahun 2020 dan Dekan FKIP yang telah memberikan fasilitas untuk kelancaran penelitian di laboratorium Biologi FKIP UNRAM.

\section{References}

Al-Bader, D. A., Shuail, D. A., Al-Hasan, R., \& Suleman, P. (2014). Intertidal seagrass Halodule uninervis: Factors controlling its density, biomass and shoot length. Kuwait Journal of Science, 41(1).

Arthana, I. W. (2004). Jenis dan kerapatan padang lamun di pantai Sanur Bali. Bumi Lestari Journal of Environment, 5(2).

Azizah, E., Nasution, S., \& Ghalib, M. (2017). Biomass and Density of Seagrass Enhalus acoroides In The Village Waters Jago-Jago Of Tapanuli Tengah North Sumatera Province (Doctoral dissertation, Riau University).

Azkab, M. H. (1999). Pedoman inventarisasi lamun. Oseana, 24(1), 1-16.

Azkab, M. H. (2006). Ada apa dengan lamun. Oseana, 31(3), 45-55.

Duarte, C. M., \& Chiscano, C. L. (1999). Seagrass biomass and production: a reassessment. Aquatic botany, 65(1-4), 159-174.

Ekaningrum, N. (2012). Kelimpahan Hewan Makrobentos Yang Berasosiasi Pada Habitat Lamun Dengan Jarak Berbeda di Perairan Pulau Pramuka Kepulauan Seribu. Management of Aquatic Resources Journal (MAQUARES), 1(1), 13-18.

Erftemeijer, P. L., Osinga, R., \& Mars, A. E. (1993). Primary production of seagrass beds in South Sulawesi (Indonesia): a comparison of habitats, methods and species. Aquatic Botany, 46(1), 67-90.

Fachrul, M.F. (2007). Metode Sampling Ekologi. Bumi Aksara.

Graha, Y. I. (2015). Simpanan Karbon Padang Lamun di Kawasan Sanur Kota Denpasar. Magister Ilmu Lingkungan Universitas Udayana Bali (Doctoral dissertation).

Graha, Y. I., Arthana, I. W., \& Karang, I. W. G. A. (2016). Simpanan karbon padang lamun di kawasan pantai sanur, kota denpasar. ECOTROPHIC: Jurnal Ilmu Lingkungan (Journal of Environmental Science), 10(1), 46-53

Hansen, J., Sato, M., Ruedy, R., Schmidt, G. A., Lo, K., \& Persin, A. (2019). Global Temperature in 2018 and beyond. Earth Institute, Columbia University: New York.

Harimbi, K. A., Taufiq-Spj, N., \& Riniatsih, I. (2019). Potensi penyimpanan karbon pada lamun spesies Enhalus acoroides dan Cymodocea serrulata di Perairan Jepara. Buletin Oseanografi Marina, 8(2), 109-115.

Helrich, K. (1990). Official methods of analysis of the Association of Official Analytical Chemists. Association of official analytical chemists.

Hilwan, I., \& Nurjannah, A. S. (2014). Potensi Simpanan Karbon Pada Tegakan Revegetasi Lahan Pasca Tambang di PT Jorong Barutama Greston, Kalimantan Selatan. Jurnal Silvikultur Tropika, 5(3), 188-195.

Houghton, J. T., Ding, Y. D. J. G., Griggs, D. J., Noguer, M., van der Linden, P. J., Dai, X., ... \& Johnson, C. A. (2001). Climate change 2001: the scientific basis. The Press Syndicate of the University of Cambridge.

Howard, J., Hoyt, S., Isensee, K., Telszewski, M., \& Pidgeon, E. (2014). Coastal blue carbon: methods for assessing carbon stocks and 
emissions factors in mangroves, tidal salt marshes, and seagrasses.

Hutomo, M., \& Nontji, A. (2014). Panduan Monitoring Padang Lamun. COREMAPCTI Lembaga Ilmu Pengetahuan Indonesia, 37.

Kuriandewa, T. E. (2009). Tinjauan tentang lamun di Indonesia. Lokakarya Nasional I Pengelolaan Ekosistem Lamun: Peran Ekosistem Lamun dalam Produktivitas Hayati dan Meregulasi Perubahan Iklim. Jakarta, 18.

Laffoley, D., \& Grimsditch, G. D. (Eds.). (2009). The management of natural coastal carbon sinks. Iucn.

Magurran, A. E. (1988). Ecological diversity and its measurement. Princeton university press.

Minerva, A., Purwanti, F., \& Suryanto, A. (2014). Analisis Hubungan Keberadaan dan Kelimpahan Lamun dengan Kualitas Air di Pulau Karimunjawa, Jepara. Management of Aquatic Resources Journal (MAQUARES), 3(3), 88-94.

Nienhuis, P. H., Coosen, J., \& Kiswara, W. (1989). Community structure and biomass distribution of seagrasses and macrofauna in the Flores Sea, Indonesia. Netherlands Journal of Sea Research, 23(2), 197-214.

Rahadiarta, I. K. V. S., Putra, I. D. N. N., \& Suteja, Y. (2019). Simpanan karbon pada padang lamun di kawasan Pantai Mengiat, Nusa Dua Bali. Journal of Marine and Aquatic Sciences, 5(1), 1-10

Rahman, F. A., Qayim, I., \& Wardianto, Y. (2018). Carbon storage variability in seagrass meadows of Marine Poton Bako, East Lombok, West Nusa Tenggara, Indonesia. Biodiversitas Journal of Biological Diversity, 19(5), 1626-1631.

Rahmawati, S. (2011). Estimasi Cadangan Karbon Pada Komunitas Lamun Di Pulau Pari,
Taman Nasional Kepulauan Seribu, Jakarta. Jurnal Segara, 7(1), 1-12.

Rinitasih, I., \& Widianingsih, W. (2010). Kelimpahan dan Pola Sebaran Kerangkerangan (Bivalve) di Ekosistem Padang Lamun, Perairan Jepara. ILMU KELAUTAN: Indonesian Journal of Marine Sciences, 12(1), 53-58.

Riniatsih, I., \& Endrawati, H. (2013). Pertumbuhan lamun hasil transplantasi jenis Cymodocea rotundata di padang lamun teluk awur jepara. Buletin Oseanografi Marina, 2(1), $34-40$.

Riniatsih, I. (2016). Distribusi Jenis Lamun Dihubungkan dengan Sebaran Nutrien Perairan di Padang Lamun Teluk Awur Jepara. Jurnal Kelautan Tropis, 19(2), 101107.

Sari, N., Syukur, A., \& Karnan, K. (2020). Kekayaan Spesies Ikan Hasil Tangkapan Nelayan Kecil pada Areal Padang Lamun di Perairan Pesisir sepanjang Pantai Lombok Tengah. Jurnal Pijar Mipa, 15(3), 252-259.

Sulaeman, S. (2005). Petunjuk Teknis Analisis Kimia Tanah, Tanaman, Air, dan Pupuk. Badan Penelitian dan Pengembangan Pertanian, Departemen Pertanian, Bogor.

Supriadi, S., Soedharma, D., \& Kaswadji, R. F. (2006). Beberapa Aspek Pertumbuhan Lamun Enhalus acoroides (Linn. F) Royle di Pulau Barrang Lompo Makassar. Majalah Ilmiah Biologi BIOSFERA: A Scientific Journal, 23(1), 1-8.

Supriadi, S., Kaswadji, R. F., Bengen, D. G., \& Hutomo, M. (2014). Carbon Stock of Seagrass Community in Barranglompo Island, Makassar (Stok Karbon pada Komunitas Lamun di Pulau Barranglompo, Makassar). Ilmu Kelautan: Indonesian Journal of Marine Sciences, 19(1), 1-10.

Wardah, B. Toknok. \& Zulkaidhah (2009). Persediaan Karbon Tegakan Agroforestri di 
Zona Penyangga Hutan Konservasi Taman Nasional Lore Lindu, Sulawesi Tengah. [Penelitian Strategi Nasional]. Universitas Tadulako, Palu, Sulawesi Tengah

Yunita, R. R., Suryanti, S., \& Latifah, N. (2020). Biodiversitas Echinodermata pada Ekosistem Lamun di Perairan Pulau Karimunjawa, Jepara. Jurnal Kelautan Tropis, 23(1), 47-56.

Yuniwati, Y., \& Suhartana, S. (2014). Potensi Karbon Pada Limbah Pemanenan Kayu Acacia Crassicarpa (Carbon Potential of Waste Timber Harvesting Acacia Crassicarpa). Jurnal Ilmu Lingkungan, 12(1), 21-31 